\title{
Active Contour Lankton untuk Segmentasi Kanker Payudara pada Citra Mammogram
}

\author{
Edy Hermawan \\ Fakultas Pendidikan Matematika dan Ilmu Pengetahuan Alam \\ IKIP PGRI Bali \\ Denpasar, Indonesia \\ e-mail: edy.hermawan87@gmail.com \\ Diajukan: 23 Juni 2019; Direvisi: 15 Juli 2019; Diterima: 9 Agustus 2019
}

\begin{abstract}
Abstrak
Mamografi merupakan salah satu alat terbaik sampai saat ini untuk melakukan deteksi dini terhadap keberadaan kanker payudara. Penggunaan mamografi efektif menurunkan tingkat kematian akibat kanker payudara sebesar 30\% sampai 70\%. Akan tetapi, terdapat kesulitan melakukan interpretasi terhadap mammogram sebagai hasil luaran dari mamografi karena sangat bergantung pada kualitas mammogram dan pengalaman dari ahli radiologi dalam mendeteksi lesi kanker payudara. Computer Aided Diagnosis(CAD) sebagai pembaca ganda mammogram dapat dipergunakan untuk meningkatkan akurasi deteksi dan segmentasi dari ahli radiologi. Penelitian ini merupakan upaya untuk melakukan deteksi dan segmentasi dengan menggunakan teknik pemrosesan citra terhadap objek yang dicurigai sebagai lesi kanker payudara pada citra mammogram. Untuk meningkatkan akurasi deteksi dan segmentasi maka dilakukan preprocessing untuk mengurangi noise dan meningkatkan homogenitas aras keabuan mammogram. Deteksi dan segmentasi terhadap keberadaan lesi kanker dilakukan dengan menerapkan metode Active Contour Lankton. Hasil penelitian menunjukkan metode yang diajukan mampu melakukan deteksi dan segmentasi terhadap lesi kanker payudara dengan baik. Wilayah kanker payudara dapat terdeteksi sesuai dengan wilayah kanker payudara yang dideteksi radiolog dan tersegmentasi dengan jelas. Fitur FO dan GLCM hasil ekstraksi dari lesi kanker payudara dapat diperoleh signifikan tanpa terlalu banyak terkontaminasi dari fitur non lesi kanker payudara. Fitur FO dan GLCM dari lesi kanker payudara hasil ekstraksi dapat dipergunakan sebagai input untuk analisis lanjutan berupa klasifikasi lesi kanker.
\end{abstract}

Kata kunci: Segmentasi, Kanker Payudara, Mammogram, Active Contour Lankton.

\begin{abstract}
Mammography is currently the best tool for early detection of the presence of breast cancer. Mammography has been shown to be effective in reducing mortality from breast cancer by $30 \%$ to $70 \%$. However, there are difficulties in interpreting mammograms as outcomes of mammography because it depends on the quality of the mammogram and the experience of the radiologist in detecting breast cancer lesions. Computer Aided Diagnosis (CAD) as a double reader mammogram can be used to improve the accuracy of detection and segmentation from a radiologist. This paper is an attempt to use image processing algorithms to process the detection and segmentation automatically of objects that are thought to be breast cancer lesions contained in mammogram images. In an effort to obtain a good level of detection and segmentation, preprocessing is imposed on mammograms to reduce noise and increase gray level homogeneity Detection and segmentation of the presence of cancer lesions is carried out by applying the Lankton Active Contour method. The results showed that the proposed method was able to detect and segment the breast cancer lesions well. The area of breast cancer can be detected according to the breast cancer region detected by the radiologist and clearly segmented. The FO and GLCM features extracted from breast cancer lesions can be obtained significantly without too much contamination from the features of non-breast cancer lesions. The FO and GLCM features of extracted breast cancer lesions can be used as input for further analysis in the form of classification of cancer lesions.
\end{abstract}

Keywords: Segmentation, Breast Cancer, Mammogram, Active Contour Lankton. 


\section{Pendahuluan}

Kanker payudara merupakan kanker yang paling banyak terdiagnosis pada wanita di seluruh dunia di mana terdapat 1,4 juta kasus pada tahun 2008. Kematian akibat kanker payudara mencapai 458.400 jiwa pada tahun 2008. Saat ini kanker payudara merupakan penyebab kematian kedua tertinggi pada wanita di seluruh dunia, setelah penyakit jantung [1].

Deteksi dan diagnosa terhadap keberadaan kanker payudara dapat dilakukan dengan beberapa prosedur di antaranya berupa diagnosa mamografi (x-ray), magnetic resonance imaging (MRI), sonography, dan termography [2]. Dari beberapa prosedur dalam melakukan deteksi dan diagnosis, mamografi merupakan peralatan yang paling efisien dalam mendeteksi dini keberadaan kanker payudara sebelum gejala fisik keberadaan kanker tersebut muncul [3]. Mamografi merupakan jenis pencitraan dengan sinar-X yang mampu memberikan gambaran visual payudara secara detail dengan memanfaatkan fitur intrinsik seperti sinar-X dosis rendah, kontras yang tinggi, film beresolusi tinggi, dan system sinar-X yang didesain khusus untuk pencitraan payudara [4] .Penggunaan mamografi sebagai deteksi dini kanker payudara sangat efektif dalam menurunkan tingkat kematian akibat kanker payudara sebesar 30\%-70\% [5].

Interpretasi mammogram oleh ahli radiologi secara langsung sering kali menghasilkan kasus positif palsu. Sekitar 52\% kesalahan diagnosa disebabkan mis-interpretasi terhadap lesi kanker pada citra mammogram, sedangkan mengabaikan tanda lesi kanker menyebabkan $43 \%$ kesalahan diagnosa[6]. Hal ini dikarenakan keakuratan dalam menafsir segmen lesi kanker yang terkandung dalam mammogram bergantung pada tingkat pengalaman ahli radiologi dan juga kualitas citra. Kesalahan diagnostik kanker payudara sering kali disebabkan oleh salah tafsir atau mengabaikan tanda-tanda kanker payudara.. Kurangnya akurasi deteksi dan segmentasi dari objek yang dicurigai sebagai kanker payudara yang terkandung pada citra mammogram sehingga terjadi kesalahan informasi fitur objek dan menyebabkan kesalahan diagnosa. Untuk mengatasi permasalahan tersebut, penggunaan computer aided diagnosis (CAD) yang dapat mengolah citra secara otomatis dan terkomputerisasi dibutuhkan untuk membantu radiolog dan dokter ahli dalam menganalisis lesi kanker payudara dalam citra mammogram dan membuat keputusan.

Tingkat akurasi dari tahapan segmentasi pada CAD menghasilkan fitur-fitur ekstraksi yang efektif untuk mengklasifikasi lesi jinak atau lesi ganas yang didasarkan pada ekstraksi terhadap kontur, bentuk dan juga tekstur dari lesi hasil segmentasi [7]. Lesi yang tersegmentasi dengan akurasi baik akan menghasilkan fitur yang reliabel karena informasi fitur terekstraksi hanya dari objek yang menjadi ROI dan tidak direduksi oleh informasi fitur objek lain.

Penelitian tentang segmentasi terhadap lesi kanker payudara pada citra digital mammogram sudah dilakukan dengan berbagai metode yang diajukan. Penelitian yang dilakukan pada [7] menggunakan metode watershed dalam tahapan segmentasi yang diajukan. Deteksi terhadap keberadaan lesi kanker dilakukan dengan deteksi tepi Canny setelah melewati tahap preprocessing. Kelemahan dari watershed adalah hasil segmentasi yang berlebih. Ukuran lesi kanker payudara yang tersegmentasi menjadi kurang akurat karena terdapat wilayah yang hilang. Penelitian [8] mengajukan metode dengan preprocessing morphology untuk menghilangkan noise. Proses deteksi dan segmentasi terbatas dilakukan untuk memisahkan kontur payudara dengan latar belakang. Sedangkan pemisahan wilayah kanker payudara terhadap wilayah non kanker payudara belum dilakukan. Penelitian yang menggunakan metode jenis Active Contour dilakukan pada [9] yaitu menggunakan maximum likelihood Active Contour. Penelitian hanya fokus pada pemisahan wilayah kanker payudara dengan wilayah non kanker dan tidak melakukan ekstraksi fitur terhadap hasil segmentasi. Dari berbagai penelitian, sampai saat ini belum ada tahapan teknik segmentasi yang menjadi standar resmi dalam mendeteksi dan menentukan objek kanker payudara pada citra mammogram. Tujuan dari penelitian ini selain menitikberatkan pada proses segmentasi wilayah kanker payudara dengan wilayah non kanker, hasil segmentasi yang diperoleh dari hasil segmentasi juga akan diekstraksi fiturnya yaitu First Order (FO) dan Gray Level Co-occurrence Matrix (GLCM) sehingga dapat dipergunakan sebagai data analisis lanjutan.

Penelitian ini dimulai dari proses preprocessing terhadap data masukan berupa citra mammogram payudara dalam dua tahapan proses. Proses pertama adalah memperhalus citra serta menghilangkan noise dengan menggunakan metode filter Gaussian. Proses kedua untuk meningkatkan kualitas dan intensitas citra mammogram melalui interpolasi dengan metode interpolasi bilinear sehingga tepi objek yang terkandung di dalam citra menjadi jelas. Citra yang telah melewati tahap preprocessing kemudian dipergunakan sebagai input dalam tahap kedua berupa tahapan segmentasi.

Segmentasi merupakan teknik untuk membagi suatu citra menjadi beberapa daerah (region) di mana setiap daerah memiliki kemiripan atribut [10]. Segmentasi terhadap keberadaan daerah lesi kanker dalam penelitian ini dilakukan dengan metode Active Contour Lankton terhadap citra mammogram yang telah melewati tahapan preprocessing. Segmentasi akan mendeteksi daerah yang terindikasi lesi kanker dan 
melakukan pemisahan objek lesi kanker dengan daerah non kanker dalam citra mammogram. Active Contour Lankton merupakan salah satu bentuk dari model Active Contour berbasis wilayah. Berbeda dengan model Active Contour berbasis wilayah yang umumnya menghitung energi minimum pada wilayah global, Active Contour Lankton melakukan pendekatan pada wilayah lokal dalam menghitung energi minimum untuk menemukan objek yang akan disegmentasi. Pendekatan dengan menghitung wilayah global pada citra yang memiliki foreground dan background heterogen serta sebaran secara statistik yang sangat dekat dapat menyebabkan kesalahan pada segmentasi karena energi diakumulasi dari keseluruhan wilayah. Pendekatan wilayah lokal menghitung energi lokal berdasarkan sebaran nilai statistik pada cakupan yang lebih kecil sehingga kedekatan sebaran dapat diperluas dan homogenitas foreground dan backgroud meningkat sehingga akurasi segmentasi juga mengalami peningkatan. Hasil segmentasi dengan Active Contour Lankton yang berbasis wilayah lokal lebih baik dari sisi hasil segmentasi citra, rerata waktu proses, serta kualitas hasil segmentasi yang lebih baik apabila dibandingkan dengan Active Contour berbasis wilayah global seperti Active Contour Chan-Vese [11].

Ekstraksi ciri dari objek hasil segmentasi pada akhirnya akan dapat dipergunakan untuk menentukan diagnosis apakah objek tersebut merupakan lesi kanker atau tidak. Ekstraksi ciri dari objek dilakukan pada fitur tekstur citra yaitu pada nilai statistik orde pertama atau First Order (FO) dan pada statistik orde kedua atau Gray Level Co-occurrence Matrix (GLCM). Nilai ini secara spesifik dapat dianalisis lebih lanjut oleh radiolog untuk menentukan jenis dari objek hasil segmentasi atau dipergunakan sebagai input untuk analisis lanjutan berupa klasifikasi lesi kanker.

\section{Metode Penelitian}

Data yang dipergunakan dalam penelitian ini merupakan citra mammogram payudara yang terindikasi mengandung lesi kanker payudara diambil dari database mammogram BCDR (Breast Cancer Digital Repository). BCDR merupakan database kanker payudara yang menyimpan citra digital mammography berserta informasi spesifik dari arsip pasien nyata yang disediakan oleh fakultas kedokteran, Universitas Porto, Portugal [12]. Citra yang dipakai dalam penelitian ini ditunjukkan pada Gambar 1.

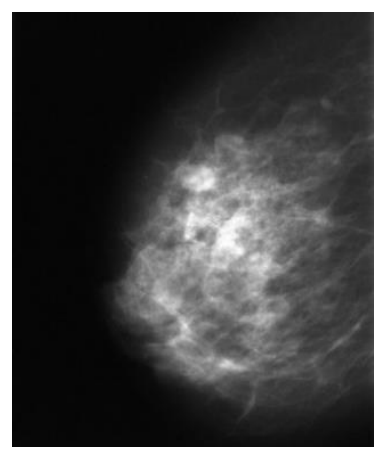

Gambar 1. Citra mammogram payudara dari BCDR.

Rancangan yang diajukan dalam penelitian ini terbagi ke dalam tiga tahapan utama yaitu (1) Preprocessing sebagai pemrosesan awal citra dengan interpolasi bilinear dan filter Gaussian, (2) Segmentasi dari objek yang dicurigai sebagai lesi kanker payudara dengan Active Contour Lankton, (3) Ekstraksi terhadap fitur statistik citra yaitu fitur First Order (FO) dan Gray Level Co-occurrence Matrix (GLCM). Gambaran umum dari rancangan penelitian ini ditampilkan pada Gambar 2. 


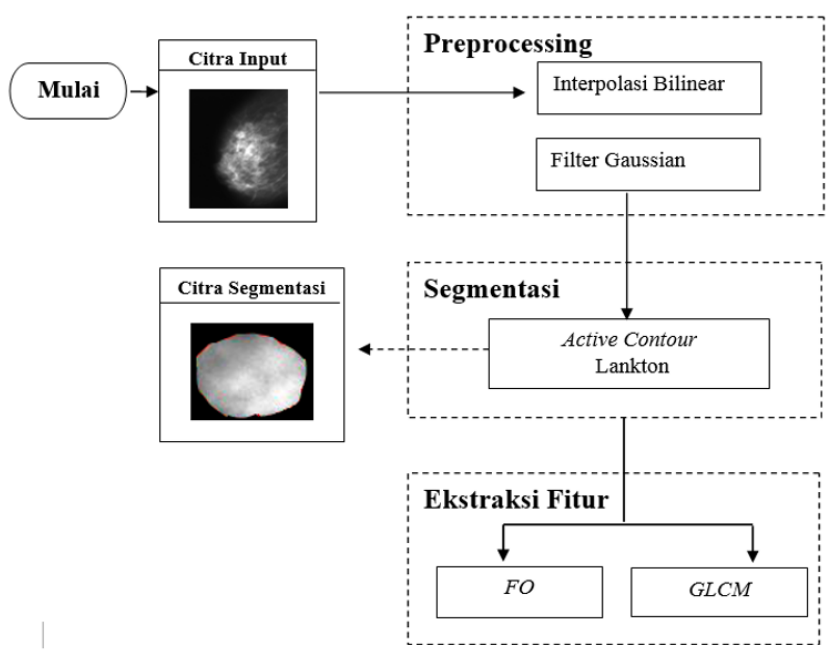

Gambar 2. Gambaran rancangan penelitian.

\subsection{Preprocessing}

Karakteristik umum dari citra medis seperti keberadaan noise, kontras citra yang buruk, tingkat homogenitas, batas citra yang lemah, serta bagian yang tidak saling terkait akan mempengaruhi konten yang akan dianalisis dari citra medis. Citra yang dihasilkan akan dapat mengandung kerusakan atau noise dikarenakan variasi acak dari intensitas, variasi pencahayaan, maupun kontras yang buruk. Karakteristik ini juga melekat dalam citra mammogram sebagai salah satu citra medis. Untuk mengatasi hal ini Gaussian filter dipilih sebagai preprocessing karena menganggap bahwa noise yang terdapat pada citra mammogram memiliki sebaran normal akibat keterbatasan sensor detektor pada perangkat mamografi.

Di samping keberadaan noise, citra medis mammogram yang diperoleh dari perangkat scan mamografi biasanya memiliki resolusi yang tidak homogen. Interpolasi yang bertujuan mengubah sampling rate atau sering disebut resampling dari pixel citra sehingga nilai skala keabuan memiliki tingkat homogenitas yang lebih tinggi baik dari sisi sebaran aras keabuan maupun dari sisi resolusi citra menjadi metode yang tepat untuk mengatasinya. Penerapan interpolasi pada citra medis memungkinkan peningkatan akurasi pengamatan pada data objek yang diobservasi karena efek tepi akibat transisi piksel dibuang atau dipindahkan ke frekuensi spasial yang cukup tinggi. Salah satu metode interpolasi yang sering dipergunakan dalam pemrosesan citra adalah interpolasi bilinear. Interpolasi bilinear merupakan metode resampling yang menggunakan rerata ukuran jarak dari empat nilai piksel terdekat untuk memperkirakan nilai piksel yang baru. Interpolasi bilinear menghitung intensitas piksel baru dengan memperhatikan distribusi empat piksel tetangga terdekat.

\subsection{Segmentasi}

Segmentasi terhadap keberadaan daerah lesi kanker dilakukan dengan metode Active Contour Lankton terhadap citra mammogram yang telah melewati tahapan preprocessing. Segmentasi akan mendeteksi daerah yang terindikasi lesi kanker dan melakukan pemisahan objek lesi kanker dengan daerah non kanker dalam citra mammogram.

Model Active Contour Lankton membagi citra ke dalam dua bagian wilayah yaitu wilayah luar (exterior) dan wilayah dalam (interior). Misal $I$ menunjukkan citra yang didefinisikan dalam domain $\Omega$, maka kontur tertutup $\mathrm{C}$ dapat direpresentasikan dalam bentuk himpunan bilangan nol (zero level set) dari $\phi$ sedemikian sehingga $C=\{x \mid \phi(x)=0\}$ dimana $x$ berupa variabel spasial yang merepresentasikan sebuah titik pada domain $\Omega$. Fungsi level set ini selalu didefinisikan sebagai fungsi jarak dengan ketentuan $\phi(x)=0$ berada pada kurva $\mathrm{C}, \phi(x)>0$ berada diluar kurva $\mathrm{C}$, dan $\phi(x)<0$ berada di dalam kurva C. Apabila digambarkan akan tampak seperti Gambar 3.

Interior dari $\mathrm{C}$ ditentukan dengan pendekatan dari fungsi Heaviside pada persamaan 1 berikut:

$$
H \phi(x)=\left\{\begin{array}{cc}
1, & \phi(x)<-\epsilon \\
0, & \phi(x)>\epsilon \\
\frac{1}{2}\left\{1+\frac{\phi}{\epsilon}+\frac{1}{\pi} \sin \left(\frac{\pi \phi(x)}{\epsilon}\right)\right\} & \text { lainnya }
\end{array}\right.
$$




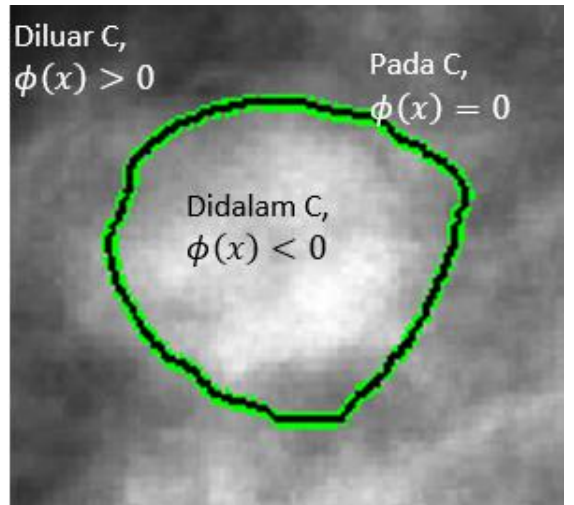

Gambar 3. Representasi levelset pada kurva C

Sedangkan eksterior dari $\mathrm{C}$ dapat didefinisikan sebagai $(1-H \phi(x))$. Untuk menentukan daerah kurva diperoleh dari turunan dari $H \phi(x)$ yang disebut Dirac delta sehingga diperoleh persamaan 2 berikut.

$$
\delta \phi(x)=\left\{\begin{array}{cc}
1, & \phi(x)=0 \\
0, & |\phi(x)|<\epsilon \\
\frac{1}{2 \epsilon}\left(1+\frac{\pi \phi(x)}{\epsilon}\right) & \text { lainnya }
\end{array}\right.
$$

Di sepanjang kurva $\mathrm{C}$ dibentuk lingkaran $\mathrm{B}(x, y)$ berupa himpunan titik ketetanggaan yang akan menjadi wilayah lokal dengan titik pusat pada titik $x$ dengan radius $\mathrm{r}$. B $(x, y)$ dipergunakan sebagai mask terhadap wilayah lokal dengan mengembalikan nilai 1 apabila titik y berada pada lingkaran dan nilai 0 bila di luar lingkaran. Dalam fungsi matematis dapat dinotasikan seperti persamaan 3 berikut.

$$
B(x, y)= \begin{cases}1, & \|x-y\|<r \\ 0, & \text { lainnya }\end{cases}
$$

Lingkaran $\mathrm{B}(x, y)$ ini dipecah menjadi dua bagian yaitu wilayah lokal dalam dan wilayah lokal luar. Hubungan $\mathrm{B}(x, y)$ dengan wilayah lokal luar dan wilayah lokal dalam dapat digambarkan seperti pada Gambar 4 [7].

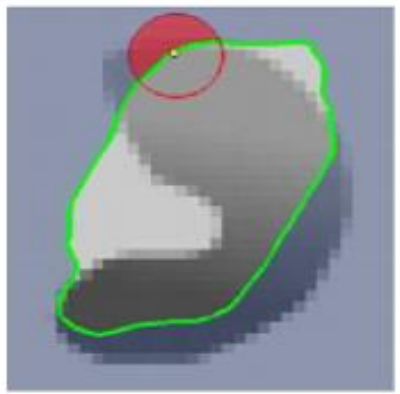

(a)

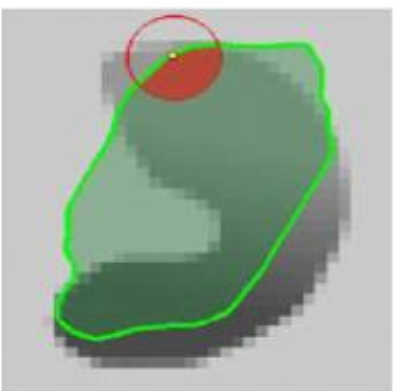

(b)

Gambar 4. (a) Wilayah lokal luar (b) Wilayah lokal dalam

Energi fungsional yang bekerja di sekeliling titik kurva kontur dihitung dengan persamaan 4 berikut:

$$
E(\phi)=\int_{\Omega x} \delta \phi(x) \int_{\Omega y} \mathrm{~B}(x, y) \cdot F(I(y), \phi(y)) d y d x+\lambda \int_{\Omega x} \delta \phi(x)\|\nabla \phi(x)\| d x
$$

Nilai F pada energi fungsional merepresentasikan ukuran energi internal generik yang menunjukkan kedekatan nilai lokal pada model di setiap titik sepanjang kontur. Energi internal $\mathrm{F}$ didefinisikan dalam persamaan 5: 


$$
F=H \phi(y)\left(I(y)-u_{x}\right)^{2}+(1-H \phi(y))\left(I(y)-v_{x}\right)^{2}
$$

Di mana $u_{x}$ dan $v_{x}$ merupakan intensitas rata-rata dari wilayah lokal dalam dan wilayah lokal luar yang didefinisikan dalam persamaan 6 dan persamaan 7 .

$$
\begin{gathered}
u_{x}=\frac{\int_{\Omega y} \mathrm{~B}(x, y) \cdot H \phi(y) \cdot I(y) d y}{\int_{\Omega y} \mathrm{~B}(x, y) \cdot(H \phi(y) d y} \\
v_{x}=\frac{\int_{\Omega y} \mathrm{~B}(x, y) \cdot(1-H \phi(y)) \cdot I(y) d y}{\int_{\Omega y} \mathrm{~B}(x, y) \cdot(1-(H \phi(y)) d y}
\end{gathered}
$$

Pergerakan energi dari perpindahan $\phi$ dapat diperoleh dari turunan pertama dari energi fungsional terhadap satuan waktu. Pergerakan perubahan energi ini dapat dibentuk sebagai persamaan 8 .

$$
\frac{\partial \phi}{\partial t}(x)=\partial \phi(x) \int_{\Omega y} \mathrm{~B}(x, y) \partial \phi(y) \cdot\left(\left(I(y)-u_{x}\right)^{2}-\left(I(y)-v_{x}\right)^{2}\right) d y+\lambda \partial \phi(x) \operatorname{div}\left(\frac{\nabla \phi(x)}{|\nabla \phi(x)|}\right)
$$

Energi minimum diperoleh ketika setiap titik pada kurva bergerak sehingga wilayah lokal dalam dan wilayah lokal luar dari setiap titik pada kurva merupakan pendekatan yang paling baik berdasarkan nilai intensitas rata-rata $u_{x}$ dan $v_{x}$.

\subsection{Ekstraksi Fitur}

Fitur adalah informasi unik yang dimiliki oleh sebuah citra. Salah satu kegunaan fitur adalah menentukan karakteristik dari sebuah citra sehingga citra tersebut dapat diklasifikasi sesuai karakteristiknya. Citra medis mammogram sebagian besar mengandung informasi yang heterogen yang menggambarkan jaringan yang berbeda seperti kulit dada, lemak, saluran serta tepi payudara. Objek lesi kanker hasil proses segmentasi pada tahap sebelumnya akan diekstraksi fitur di dalamnya sebagai hasil analisis. Ekstraksi fitur dilakukan pada fitur First Order (FO) dan Gray Level Cooccurence Matrix (GLCM).

Ekstraksi first order (FO) merupakan metode pengambilan ciri yang didasarkan pada karakteristik histogram citra. Histogram menunjukkan probabilitas kemunculan nilai derajat keabuan piksel pada suatu citra. Dari nilai-nilai pada histogram yang dimiliki objek lesi kanker payudara sebagai ROI akan dihitung beberapa parameter First Order (FO), yaitu mean, standard deviasi, smoothness, skewness, uniformity dan entropy [13].

Mean menunjukkan ukuran dispersi dari suatu citra, dapat dihitung dengan persamaan 9.

$$
m=\sum_{u=0}^{n-1} f_{u} p\left(f_{u}\right)
$$

Di mana $f u$ adalah suatu nilai intensitas keabuan, $p(f u)$ menunjukkan nilai histogramnya (probabilitas kemunculan intensitas tersebut pada citra), dan $\mathrm{n}$ adalah nilai tertinggi dari intensitas.

Standard deviasi menunjukkan variasi elemen pada histogram dari suatu citra didefinisikan dalam persamaan 10 berikut:

$$
\sigma=\sqrt{\sum_{u=0}^{n-1}\left(f_{u}-m\right)^{2} p\left(f_{u}\right)}
$$
persamaan 11

Smoothness menunjukkan tingkat kehalusan relative dari intensitas suatu citra didefinisikan dalam

$$
R=1-\frac{1}{1+\sigma^{2}}
$$

Skewness menunjukkan tingkat kecondongan relative histogram dari suatu citra didefinisikan dalam persamaan 12 :

$$
\mu_{3}=\sum_{u=0}^{n-1}\left(f_{u}-m\right)^{3} p\left(f_{u}\right)
$$


Uniformity menunjukkan tingkat keseragaman intensitas dari suatu citra didefinisikan dalam persamaan 13 berikut:

$$
U=\sum_{u=0}^{n-1} p^{2}\left(f_{u}\right)
$$
14 berikut:

Entropy menunjukkan ukuran ketidakaturan bentuk dari suatu citra didefinisikan dalam persamaan

$$
e=-\sum_{u=0}^{n-1} p\left(f_{u}\right) \log _{2} p\left(f_{u}\right)
$$

Selain ekstraksi First Order(FO) juga dilakukan ekstraksi orde dua yang disebut juga dengan Gray Level Co-occurrence Matrix (GLCM). Teknik untuk memperoleh ciri statistik orde dua adalah dengan menghitung probabilitas hubungan ketetanggaan antara dua piksel pada jarak dan orientasi sudut tertentu. Pendekatan ini bekerja dengan membentuk sebuah matriks kookurensi dari data citra, dilanjutkan dengan menentukan ciri sebagai fungsi dari matriks antara tersebut[13]

Matriks kookurensi berbentuk matriks bujur sangkar dengan jumlah elemen sebanyak kuadrat jumlah level intensitas piksel pada citra. Setiap titik $(i, j)$ pada matriks kookurensi berorientasi $\theta$ berisi peluang kejadian piksel bernilai $i$ bertetangga dengan piksel bernilai $j$ pada jarak $d$ serta orientasi $\theta$ dan (180- $\theta$ ). Sebelum ciri statistik fitur dapat dihitung, diperlukan normalisasi matriks yaitu nilai probabilitas setiap piksel terhadap jumlah nilai keseluruhan piksel. Persamaan normalisasi didefinisikan dalam persamaan 15 berikut:

$$
p(i, j)=\frac{V(i, j)}{\sum_{i, j=0}^{N-1} V(i, j)}
$$

Ciri statistik fitur yang dihitung adalah Contrast, Correlation, Energy, Homogeneity. Contrast menunjukkan ukuran penyebaran elemen-elemen matriks citra yang didefinisikan dalam bentuk persamaan 16.

$$
\text { Contrast }=\sum_{i, j=0}^{N-1}(i-j)^{2} p(i, j)
$$

Energy menunjukkan ukuran konsentrasi pasangan intensitas pada matriks kookurensi. Energy didefinisikan dengan persamaan :

$\sum_{i, j=0}^{N-1} p(i, j)^{2}$

$$
\text { Energy }=
$$

Homogeneity menunjukkan kehomogenan citra yang berderajat keabuan sejenis didefinisikan dengan persamaan:

$$
\text { Homogeneity }=\sum_{i, j=0}^{N-1} \frac{p(i, j)}{1+(i-j)^{2}}
$$

Correlation menunjukkan ukuran ketergantungan linear derajat keabuan citra sehingga dapat memberikan petunjuk adanya struktur linear dalam citra dan didefinisikan dengan persamaan 19.

$$
\text { Correlation }=\sum_{i, j=0}^{N-1} \frac{\left(i-u_{i}\right)\left(j-u_{j}\right) p(i, j)}{\sigma_{i} \sigma_{j}}
$$

Dalam penelitian ini orientasi GLCM dibentuk dalam empat arah sudut dengan interval sudut 45 derajat, yaitu $0^{\circ}, 45^{\circ}, 90^{\circ}$, dan $135^{\circ}$,sedangkan jarak antar piksel ditetapkan sebesar 1 piksel.

\section{Hasil dan Pembahasan}

Implementasi terhadap metode segmentasi dilakukan dengan menggunakan perangkat lunak Matlab. Untuk memudahkan menandai posisi objek kanker payudara dilakukan pemotongan citra mammogram pada sekitar objek yang dicurigai oleh dokter ahli sebagai lokasi kanker payudara sehingga diperoleh citra berukuran 512x512 piksel. Proses preprocessing terhadap citra ini kemudian dilakukan dengan filter Gaussian untuk mengurangi noise yang terkandung di dalamnya. Setelah proses minimalisasi 
noise selesai, dilanjutkan dengan interpolasi bilinear untuk meningkatkan homogenitas baik dari sisi sebaran aras keabuan maupun dari sisi resolusi citra. Hasil tahapan preprocessing ditunjukkan pada Gambar 6.

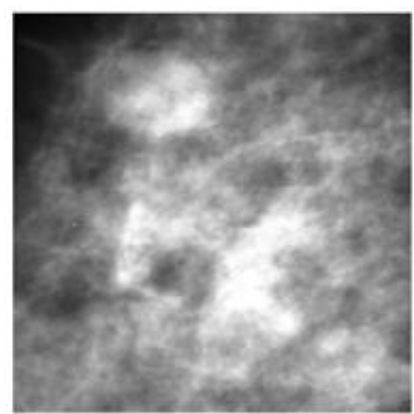

(a)

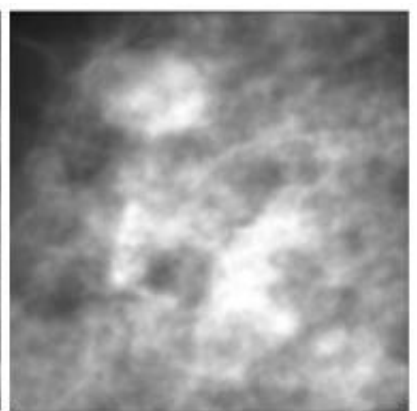

(b)

Gambar 5. (a) Citra mammogram awal (b) Citra mammogram preprocessing

Kurva kontur awal merupakan penanda awal posisi yang dicurigai sebagai objek lesi kanker payudara yang terkandung pada mammogram. Tahap awal dari proses segmentasi adalah menentukan kurva awal berdasarkan tanda posisi awal dari radiolog. Kurva akan bergerak dengan melakukan minimasi energi pada wilayah lokal sampai kondisi iterasi terpenuhi. Selanjutnya levelset di dalam kurva C dengan nilai $\phi(x)<0$ ditandai sebagai objek lesi hasil segmentasi dan wilayah diluar kurva akan diberi nilai 0 sebagai background. Proses dari inisialisasi kurva awal sampai citra tersegmentasi ditunjukkan pada Gambar 7.

Tahapan terakhir dari penelitian ini adalah proses ekstraksi fitur dari objek lesi kanker payudara hasil segmentasi. Dengan mengekstraksi fitur statistik dari objek lesi tersebut maka dokter ahli dapat mendiagnosis berdasarkan data yang diperoleh. Atau dengan menggunakan teknik klasifikasi dapat dilakukan diagnosa dengan bantuan komputer sebagai diagnosa pembanding. Citra yang dipakai dalam penelitian ini ditunjukkan pada Gambar 8 berikut.

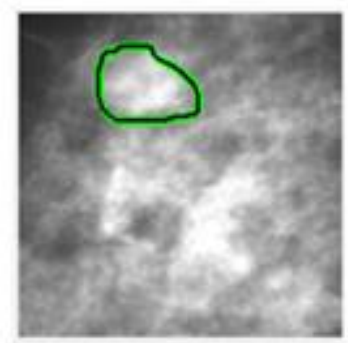

(a)

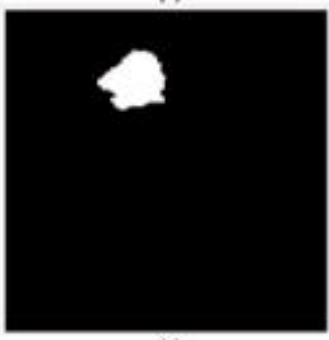

(c)

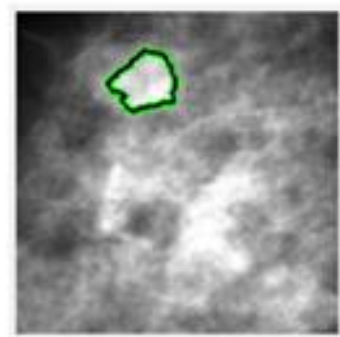

(b)

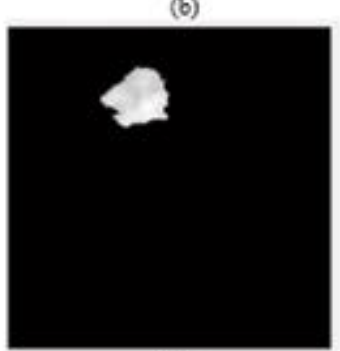

(d)

Gambar 6. (a) Inisialisasi kurva awal, (b) Kurva akhir hasil deteksi, (c) Penanda background objek lesi kanker, (d) Objek lesi kanker payudara. 

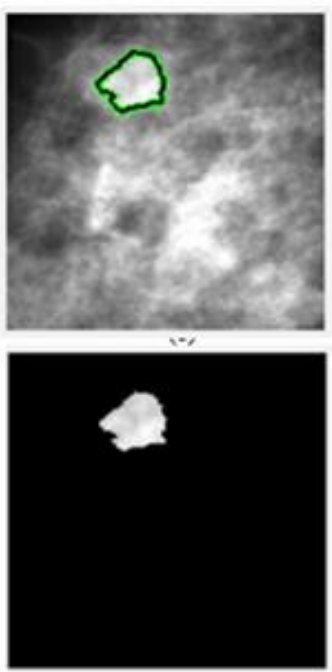

(a)
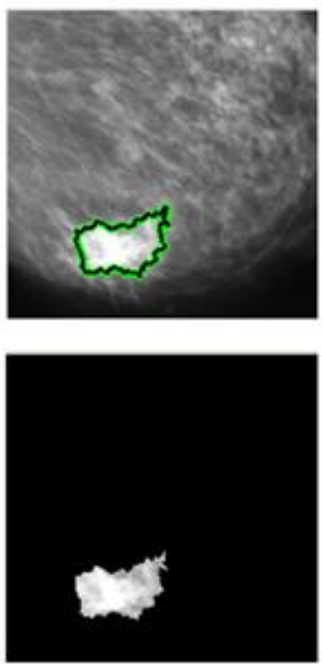

(b)

Gambar 7. Citra uji hasil teknik segmentasi dengan Active Contour Lankton (a) Citra uji 1 (b) Citra uji 2

Adapun nilai statistik dari fitur First Order (FO) dari citra pada Gambar 8 ditampilkan pada Tabel 1 sedangkan nilai fitur Gray Level Co-occurrence Matrix (GLCM) pada arah $0^{\circ}, 45^{\circ}, 90^{\circ}$ dan $135^{\circ}$ ditampilkan pada Tabel 2 dan Tabel 3.

Tabel 1. Nilai Fitur First Order.

\begin{tabular}{ccccccc}
\hline Citra & Mean & StDev & Smooth & Skew & Uniformity & Entropy \\
\hline Uji 1 & 6.53 & 40.28 & 0.024 & 6.038 & 0.95 & 0.172 \\
\hline Uji 2 & 10.02 & 49.5 & 0.04 & 8.87 & 0.92 & 0.24 \\
\hline
\end{tabular}

Tabel 2. Nilai Fitur Contrast dan Correlation GLCM.

\begin{tabular}{ccccccccc}
\hline \multirow{2}{*}{ Citra } & \multicolumn{4}{c}{ Contrast } & \multicolumn{4}{c}{ Correlation } \\
\cline { 2 - 9 } & $\mathbf{0}^{\mathbf{0}}$ & $\mathbf{4 5}^{\mathbf{0}}$ & $\mathbf{9 0}^{\mathbf{0}}$ & $\mathbf{1 3 5}^{\mathbf{0}}$ & $\mathbf{0}^{\mathbf{0}}$ & $\mathbf{4 5}^{\mathbf{}}$ & $\mathbf{9 0}^{\mathbf{o}}$ & $\mathbf{1 3 5}^{\mathbf{0}}$ \\
\hline Uji 1 & 0.013 & 0.013 & 0.18 & 0.152 & 0.97 & 0.96 & 0.96 & 0.95 \\
\hline Uji 2 & 0.276 & 0.44 & 0.30 & 0.375 & 0.95 & 0.93 & 0.95 & 0.94 \\
\hline
\end{tabular}

Tabel 3. Nilai Fitur Contrast dan Correlation GLCM.

\begin{tabular}{ccccccccc}
\hline \multirow{2}{*}{ Citra } & \multicolumn{1}{c}{ Energy } & \multicolumn{9}{c}{ Homogenity } \\
\cline { 2 - 10 } & $\mathbf{0}^{\mathbf{o}}$ & $\mathbf{4 5}^{\mathbf{0}}$ & $\mathbf{9 0}^{\mathbf{0}}$ & $\mathbf{1 3 5}^{\mathbf{0}}$ & $\mathbf{0}^{\mathbf{0}}$ & $\mathbf{4 5}^{\mathbf{0}}$ & $\mathbf{9 0}^{\mathbf{0}}$ & $\mathbf{1 3 5}^{\mathbf{0}}$ \\
\hline Uji 1 & 0.13 & 0.12 & 0.13 & 0.11 & 0.93 & 0.90 & 0.92 & 0.89 \\
\hline Uji 2 & 0.09 & 0.07 & 0.08 & 0.07 & 0.86 & 0.81 & 0.85 & 0.82 \\
\hline
\end{tabular}

\section{Kesimpulan}

Berdasarkan hasil penelitian diperoleh bahwa teknik segmentasi yang diajukan mampu mendeteksi lesi kanker payudara yang terkandung dalam citra mammogram berdasarkan besaran energi lokal berdasarkan inisialisasi kurva awal. Dengan melewati tahap preprocessing berupa filter Gaussian dan interpolasi citra mampu meningkatkan akurasi dari nilai fitur yang diperoleh karena berkurangnya gangguan berupa noise yang terkandung dalam citra dan meningkatnya homogenitas dari sebaran piksel citra. Tahap segmentasi dengan metode Active Contour Lankton mampu merekonstruksi kurva awal dengan membentuk kurva tertutup baru mendekati energi lokal yang terkandung pada objek lesi kanker. Semakin meningkat akurasi dari deteksi dan segmentasi objek lesi maka akan berpengaruh positif terhadap diagnosis akhir. Hasil akhir dari sistem juga telah mampu melakukan ekstraksi fitur statistik terhadap hasil segmentasi berupa nilai First Order (FO) yaitu mean, standar deviasi, smoothness, skewness, uniformity, dan entropy dengan hasil seperti pada Tabel 1. Nilai fitur GLCM berupa contrast, correlation, energy, dan homogenity dalam besar sudut $0^{\circ}, 45^{\circ}, 90^{\circ}$, dan $135^{\circ}$ juga telah dapat diekstraksi seperti dalam Tabel 2 dan Tabel 3. Dengan menggunakan nilai-nilai fitur tersebut dapat dilakukan penelitian lanjutan untuk melakukan klasifikasi dengan menggunakan metode klasifikasi seperti jaringan saraf tiruan dan metode lainnya 
terhadap objek lesi hasil segmentasi sehingga akan dapat menghasilkan diagnosis pembanding bagi radiolog maupun dokter ahli.

\section{Daftar Pustaka}

[1] American Cancer Society, Breast Cancer Facts and Figures 2013-2014. Atlanta: American Cancer Society, Inc, 2014.

[2] J. E. Joy, E. E. Penhoet, and D. B. Petitti, Saving Women's Lives - Strategies for Improving Breast Cancer Detection and Disgnosis. 2005.

[3] W. E. Fathy and A. S. Ghoneim, "A Deep Learning Approach for Breast Cancer Mass Detection," Int. J. Adv. Comput. Sci. Appl., vol. 10, no. 1, pp. 175-182, 2019.

[4] M. Helms, R.L., O'Hea, E.L. and Corso, "Body image issues in women with breast cancer," Psychol. Heal. Med., vol. 13, no. 3, pp. 313-325, 2008.

[5] L. M. Mina and N. A. M. Isa, "A review of computer-aided detection and diagnosis of breast cancer in digital mammography," J. Med. Sci., vol. 15, no. 3, pp. 110-121, 2015.

[6] R. M. Rangayyan, F. J. Ayres, and J. E. Leo Desautels, "A review of computer-aided diagnosis of breast cancer: Toward the detection of subtle signs," J. Franklin Inst., vol. 344, no. 3-4, pp. 312-348, 2007.

[7] J. Sharma and S. Sharma, "Mammogram image segmentation using watershed," Int. J. Inf. Technol. Knowl. Manag., vol. 4, no. 2, pp. 423-425, 2011.

[8] A. Sahakyan and H. Sarukhanyan, "Segmentation of the Breast Region in Digital Mammograms and Detection of Masses," Int. J. Adv. Comput. Sci. Appl., vol. 3, no. 2, pp. 102-105, 2012.

[9] P. Rahmati, A. Adler, and G. Hamarneh, "Mammography segmentation with maximum likelihood Active Contours," Med. Image Anal., vol. 16, no. 6, pp. 1167-1186, 2012.

[10] D. Putra, Pengolahan Citra Digital. Penerbit Andi, 2010.

[11] D. Apriliani and Murinto, "Analisis Perbandingan Teknik Segmentasi Citra Digital Menggunakan Metode Level Set," vol. 7, no. 2, pp. 802-810, 2013.

[12] M. A. López Guevara et al., "Bcdr: a Breast Cancer Digital Repository," 15 Int. Conf. Exp. Mech., no. January, pp. 1-5, 2012.

[13] R. C. Gonzalez, R. E. Woods, and S. L. Eddins, Digital image processing using MATLAB. Publisher T. Robins, 2009. 